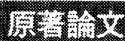

\section{術前輸液と術中 $A D H$}

助永和子* 河野克彬* 津田三郎* 石田博厚*

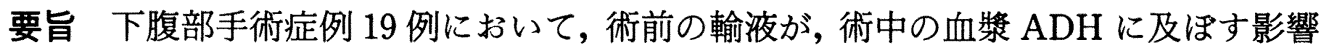
について検討した. 術前の輸液量によって 2 群に分け，それぞれ Control 群, Hydration 群とした. (1)術前輸液開始前 8：00 A.M., (2)麻酔直前, (3)麻酔 15 分, (4)執刀後 10 分, (5) 30 分, (6) 60 分, (7)手術終了直後に静脈採血した. 血漿 ADH レベルは, C 群で は, (平均 $\pm \mathrm{SEM}$ ) (1) $3.1 \pm 0.9 \mathrm{pg} / \mathrm{ml}$ (2) $3.2 \pm 0.9$ (3) $2.7 \pm 0.6$ (4) $45.1 \pm 12.7$ (5) $19.5 \pm 4.0$ (6) $17.9 \pm 5.1$ (7) 18.6 44.1 であり, $\mathrm{H}$ 群では(1) $3.7 \pm 0.5$ (2) $3.9 \pm 0.6$ (3) $3.1 \pm 0.6$ (4) $84.9 \pm$ 30.7 (5) 47.6 414.9 (6) $24.5 \pm 5.2$ (7) $23.0 \pm 7.0$ で両群間に統計上差がなく, 本検討におけ る術前の輸液方法では，術中の血漿 $\mathrm{ADH}$ に影響を与えないといえる。

\section{I はじめに}

術前の脱水は, 手術侵襲に対する Renin-Angiotensin 系の反応を増強させる可能性が考え られ5)，著者らは，上腹部手術症例において，手 術直前の 100 分間に $1000 \mathrm{ml}$ のハルトマン液 を輸注し, 十分細胞外液を増加させると, 手術 中の血槳 Aldosteroneの上昇が, 非輸液群に比 して抑制されることを示した ${ }^{1)}$. 今回, 術前の輸 液が，術中の血漿 $\mathrm{ADH}$ の上昇を抑制するので はないかと推測し, 下腹部手術症例において, 同様に検討した。

\section{II 対象および方法}

対象は, 午後 1 時麻酔開始予定の全身状態良
好な単純子宮全摘例 19 例で, 術前の輸液方法に よって, Control 群と Hydration 群の 2 群に分 けた。両群間の年齢, 体重, 体表面積には, 差 はなかった（表 1 ）。

前投薬として, Hydroxyzine $50 \mathrm{mg}$ と Atropine Sulfate $0.5 \mathrm{mg}$ を, 麻酔開始 30 分前に筋注 した. Thiamylal $4 \sim 5 \mathrm{mg} / \mathrm{kg}$, S.C.C. $1 \mathrm{mg} / \mathrm{kg}$ によって麻酔導入, 気管内挿管し, 以後は GOF+Pancuronium bromide で麻酔を維持し た. 術中の出血量は, 全例 $500 \mathrm{~m} l$ 以下で, 輸血 を要したものはなく，また，低血圧になったも

表 1 対象症例の年齡・体重・体表面樌

\begin{tabular}{|c|c|c|c|c|}
\hline Group & $n$ & Age $(y / 0)$ & BW $(\mathrm{kg})$ & BSA $\left(\mathrm{m}^{2}\right)$ \\
\hline Control & 9 & $41.0 \pm 7.2$ & $53.6 \pm 5.6$ & $1.51 \pm 0.12$ \\
\hline Hydration & 10 & $43.5 \pm 3.3$ & $53.0 \pm 3.2$ & $1.50 \pm 0.07$ \\
\hline
\end{tabular}




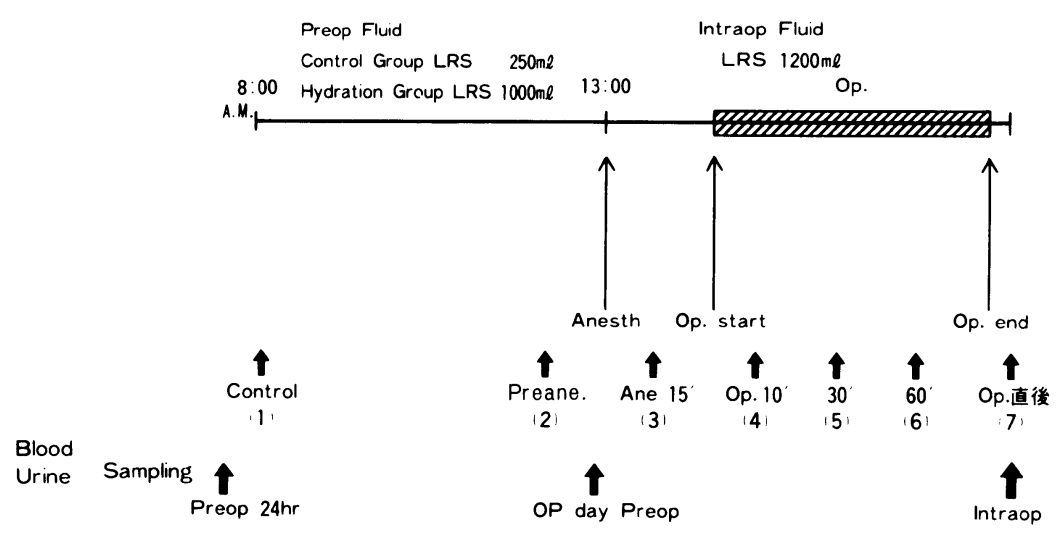

Components measured: P-ADH. P-Ald. P-osm. U-osm. UV.

図 1 検討方法

のもない.

Control 群 (以下C群と略す, 9 例) では, 手 術当日朝 8 時より手術直前までの 5 時間に, $8 \%$ Glucose 加 LRS を $250 \mathrm{ml}$, Hydration 群（以 下H群と略す, 10 例) では, 同時期に $2 \%$ Glucose 加 LRS $1000 \mathrm{~m} l$ 輸液し, 両群とも Glucose の投与量が $20 \mathrm{~g}$ となるようにした。術中 の輸液は, 全例, $1 \%$ Glucose 加 LRS に KCl $5 \mathrm{mEq} / l$ 添加したものを, 初めの 30 分間に 500 $\mathrm{m} l$, 以後 $500 \mathrm{ml} / \mathrm{h}$ で投与した. 投与量は, い ずれも約 2 時間の麻酔中に，ほほ $1200 \mathrm{ml}$ であ つた.

静脈採血を(1)術前輸液開始前 8：00 A.M., (2) 麻酔直前, (3)麻酔 15 分, (4)執刀後 10 分, (5) 30 分, (6) 60 分, (7)手術終了直後に行ない, 尿に関 しては，手術前日全尿をコントロールとし，麻 酔開始までの 5 時間尿および術中尿を採取し て，血漿 $\mathrm{ADH} \cdot$ Aldosterone レベル，血漿浸透 圧 (P-osm). 尿浸透圧 (U-osm), 尿量 (UV) を測定した（図 1).ADH は, D.M. Philbin ら による Radiommunoassay 法6)により, Aldosterone は, ダイナボット社製 RIA キットによ
り，浸透圧は, Wescor Vapor Pressure Osmometerにより測定した.

\section{III 結 果}

血槳 $\mathrm{ADH}$ は，(それぞれ，平均 $\pm \mathrm{SEM} て ゙$ 示 す) C 群では, (1) $3.1 \pm 0.9 \mathrm{pg} / \mathrm{ml}$ (2) $3.2 \pm 0.9$ (3) $2.7 \pm 0.6$ (4) $45.1 \pm 12.7$ (5) $19.5 \pm 4.0$ (6) $17.9 \pm 5.1$ (7) $18.6 \pm 4.1$ であり, H 群では, (1) $3.7 \pm 0.5$ (2) $3.9 \pm 0.6$ (3) $3.1 \pm 0.6$ (4) $84.9 \pm 30.7$ (5) $47.6 \pm 14.9$ (6) $24.5 \pm 5.2$ (7) 23.0 \pm 7.0 であった. $8: 00$ A.M. のコントロール值は, 両群とも $3 \sim 4 \mathrm{pg} / \mathrm{m} l$ で 正常範囲内にあった.また麻酔開始直前の值も, コントロール值と変化がなく, 輸液量の大小と も無関係であった。さらに，術中 $\mathrm{ADH}$ の上昇 は, 手術開始後 10 分で最高となり, C 群で 45.1 $\mathrm{pg} / \mathrm{m} l, \mathrm{H}$ 群で $84.9 \mathrm{pg} / \mathrm{m} l$ に上昇し, 手術終了 直後には,それぞれ, $18.6 \mathrm{pg} / \mathrm{m} l, 23.0 \mathrm{pg} / \mathrm{m} l$ と 低下したが，依然コントロール值より有意に高 值であった $(\mathrm{P}<0.025, \mathrm{P}<0.025)$ (図 2$)$. しか し, 両群間には統計上差がなかった.すなわち, 術前の hydration が, 術中の血漿 $\mathrm{ADH}$ の上昇 を抑制しなかったといえる。 


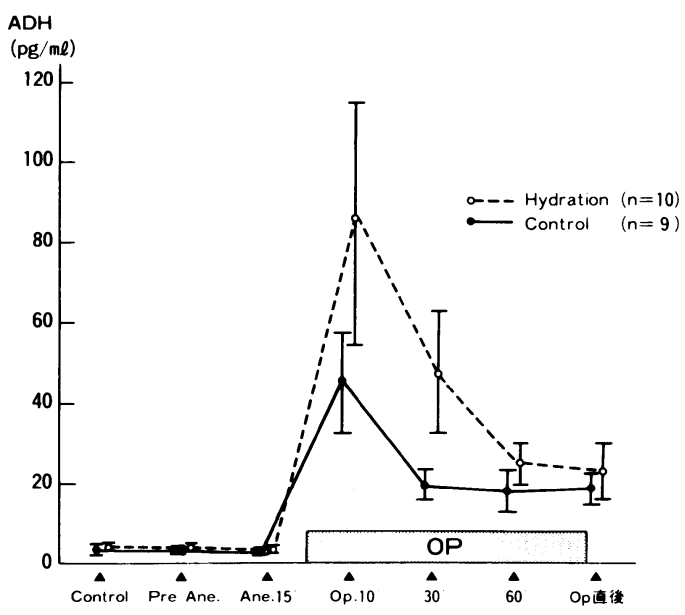

図 2 血漿 ADH の変化
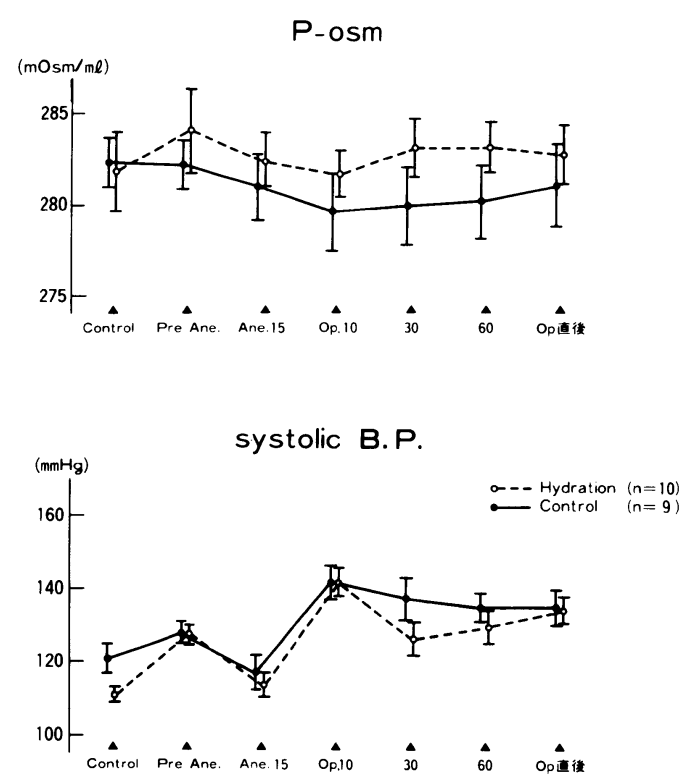

図 3 血漿漫透圧と収縮期血圧の推移

血漿浸透圧の変化は, $\mathrm{ADH}$ 分泌の一因子で あるが, C群では, 術前輸液前後で, (1) 282 $\mathrm{mOsm} / l$ (2) $282 \mathrm{mOsm} / l$ と差がなく, $\mathrm{H}$ 群で は, (1) $282 \mathrm{mOsm} / l$ (2) $284 \mathrm{mOsm} / l$ と軽度の上 昇を認めたものの, 術中は両群とも, 全経過を 通じて著変がなかった（図 3 )。

ストレスの 1 つの指標となる収縮期血圧は,

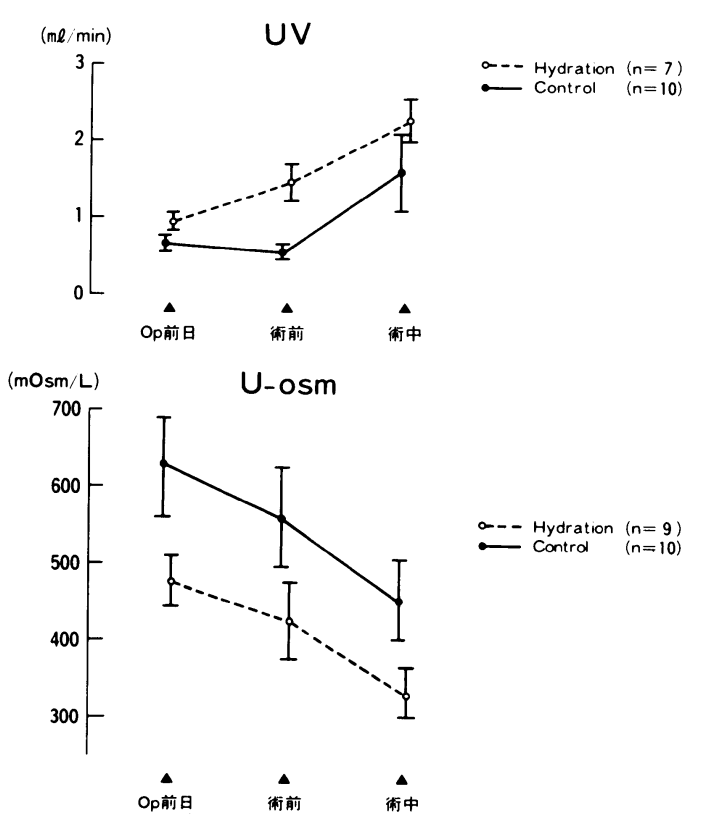

図 4 尿量と尿漫透圧の推移

$\mathrm{ADH}$ の推移にほほ平行し, 両群とも, 執刀後 10 分以後有意の上昇を示した $(\mathrm{P}<0.05, \mathrm{P}<0.05)$ (図 3 ).

尿量は, C 群では, 手術前日 $0.68 \pm 0.07 \mathrm{ml} /$ $\min ($ mean $\pm S E M)$, 術前 $0.54 \pm 0.07 \mathrm{ml} / \mathrm{min}$, 術中 $1.6 \pm 0.5 \mathrm{ml} / \mathrm{min}$ で有意の変化はなかった が, $\mathrm{H}$ 群では, 手術前日 $0.95 \pm 0.09 \mathrm{ml} / \mathrm{min}$, 術 前 $1.46 \pm 0.26 \mathrm{ml} / \mathrm{min}$, 術中 $2.25 \pm 0.29 \mathrm{ml} / \mathrm{min}$ と有意の増加を示した $(\mathrm{P}<0.05)$. 術前・術中の $\mathrm{H}$ 群の尿量が C 群より多いようであったが, 統 計上，両群間に差はなかった（図 4 ）。

尿浸透圧は, C 群では, 手術前日 $630 \pm 62$ $\mathrm{mOsm} / l$ (mean $\pm \mathrm{SEM}$ ), 術前 $558 \pm 68 \mathrm{mOsm} /$ $l$, 術中 $453 \pm 54 \mathrm{mOsm} / l$ であり, $\mathrm{H}$ 群では, 手 術前日 $475 \pm 35 \mathrm{mOsm} / l$, 術前 $423 \pm 52 \mathrm{mOsm} /$ $l$, 術中 $330 \pm 34 \mathrm{mOsm} / l$ で, 両群とも術中に有 意の低下となったが $(\mathrm{P}<0.05, \mathrm{P}<0.05)$, 両群 間に統計上差はなかった（図 4 ).

血漿 Aldosterone は, (mean \pm SEM) C 群で 


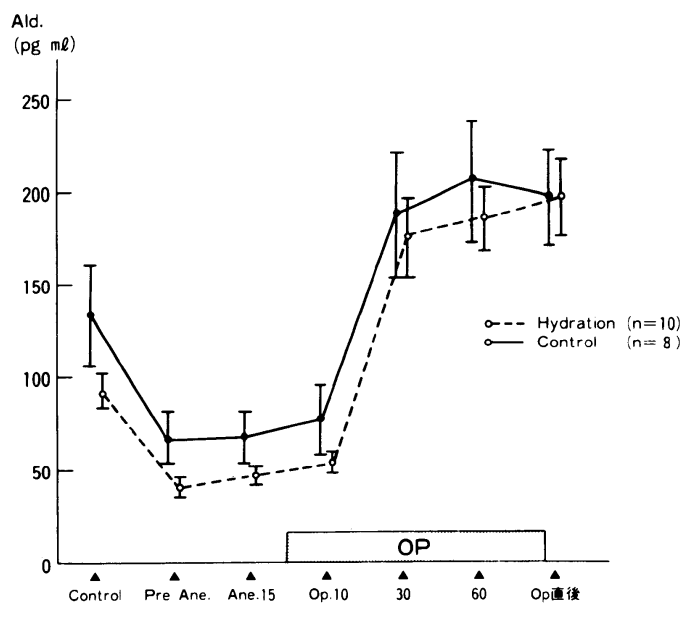

図 5 血漿 Aldosterone の変化

は (1) $133.5 \pm 27.6 \mathrm{pg} / \mathrm{m} l$ (2) $66.6 \pm 15.9$ (3) $67.5 \pm$ 14.6 (4) $75.8 \pm 19.9$ (5) $187.1 \pm 34.4$ (6) $205.1 \pm 32.2$ (7) $196.4 \pm 26.3$ で H 群では (1) $93.1 \pm 9.2$ (2) $40.5 \pm 4.5$ (3) $47.0 \pm 5.4$ (4) $53.1 \pm 5.8$ (5) $175.5 \pm$ 21.2 (6) $185.9 \pm 19.2$ (7) 197.7 21.2 であり, 両群 とも, 麻酔前, 麻酔 15 分, および手術開始後 10 分には術前輸液前の值より低下したが，手術開 始 30 分以後では上昇し, 両群間に差はみられな かった（図 5 ).

血漿・尿のナトリウム, カリウムは, 両群と も全経過を通じて変化しなかった。

BUN や血漿クレアチニンは, 両群とも, ほと んどすべての時期にコントロールより低下して いたが，両群間に差はなかった。

尿 UN やクレアチニン排泄量は増加してお らず, $\mathrm{H}$ 群での尿量の増加は, 溶質を伴わない 水だけの排泄の増加によるものと思われる.

\section{IV 考 察}

上腹部手術症例で, 手術直前の 100 分間に $1000 \mathrm{~m} l$ のハルトマン液の輸注が，手術中の血

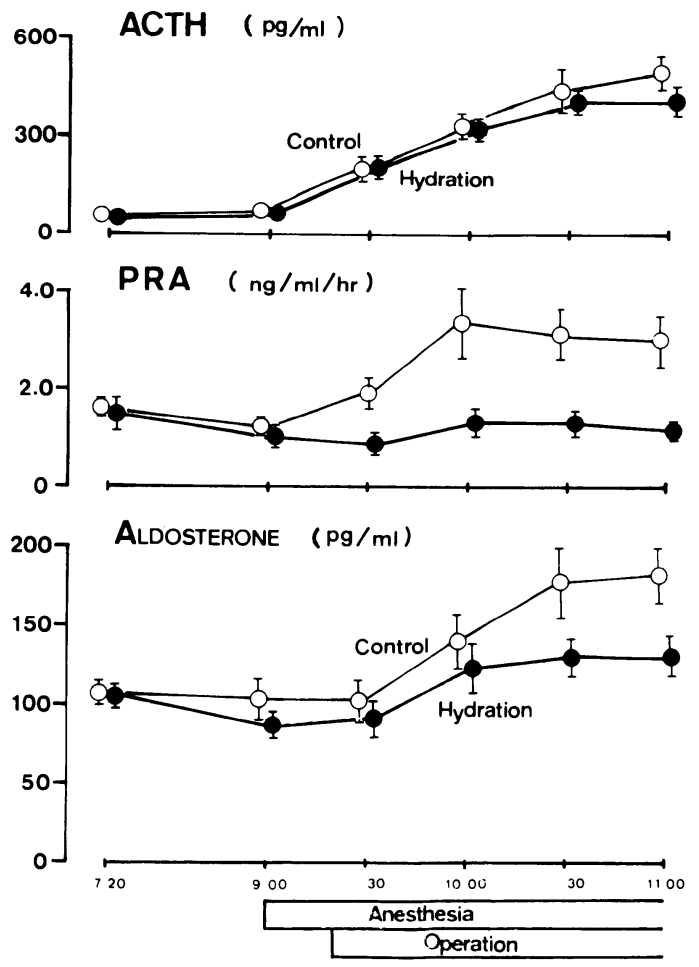

図6 血漿 ACTH, Renin, Aldosterone の推移 ${ }^{1)}$

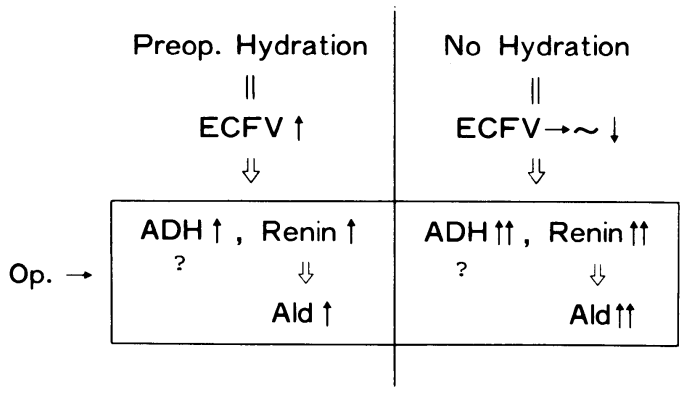

図 7

漿 Aldosteroneの上昇を抑制することを報告 したが（図 6 )，この血漿 Aldosterone の抑制 は, 図 7 のごとく, ECFV の増大による ReninAngiotensin 系の抑制を介したものであり，体 液量と密接な関係にある血漿 $\mathrm{ADH}$ も，同様に その上昇が抑制されるのではないかと推測し た2).ところが, 本検討では予想に反し, 術前の hydration は, 術中の ADH・Aldosterone 両者 
の変化に影響しなかった，その理由として(1)同 じ $1000 \mathrm{~m} l$ の輸液でも, hydration が 5 時間に わたったということ（すなわち, 輸液速度が遅 すぎた). (2) $\mathrm{H}$ 群の麻酔直前の水バランスは $+500 \mathrm{~m} l$ であり, C 群に比較して $400 \mathrm{~m} l$ 多か ったが,この程度の positive balance では, ECF の volume expansion が不十分であったこと.

(3) $\mathrm{ADH}$ と Aldosterone は分泌機序が異なり, $\mathrm{ECFV}$ の増大に対する感受性が $\mathrm{ADH}$ でより 低いため, 術前の輸液が, 術中の $\mathrm{ADH}$ 分泌に影 響を与えなかった. (4)手術術式の違い, の 4 つ が考えられる.また図 5 に示したごとく, Aldosterone も両群間に差がなかったことは, (1)と(2) の関与を裏づけるものである.

手術侵襲に対する Aldosterone の上昇が, $\mathrm{ADH}$ よりも時期的に遅れていたことは, Aldosterone 分泌には time lag があり, ADH の分 泌が,より速やかであることを示すものであ $ろ^{2,3)}$.

$\mathrm{ADH}$ の著しい上昇は, splanchnic artery や coronary artery の vasoconstrictionを来した り，術中の腎における水分の再吸収を増加させ るなどの望ましくない作用があり4), 手術中の $\mathrm{ADH}$ の分泌を抑制することは, 生体にとって より好ましいと考えられる。

術中の $\mathrm{ADH}$ 分泌の刺激として考えられる因 子としで2,

(1) baroreceptor を介した血圧・心拍出量の 低下

(2)痛み

(3) volume receptor を介した左房圧の低下

(4)血漿浸透圧の上昇 ${ }^{7)}$

(5)麻酔剂8)

(6)陽圧呼吸9)

などがあるが(1)の影響が最も大きく，(4)や(6)に
よる $\mathrm{ADH}$ の上昇は小さいとされている。

今回，著者らは， $\mathrm{C}$ 群と $\mathrm{H}$ 群の痛み刺激を同 じものと仮定し，術前に輸液をすることによっ て，(3)を介した $\mathrm{ADH}$ の分泌を抑制することが できるのではないかと考えた。しかし，今回の 検討では, $\mathrm{C}$ 群と $\mathrm{H}$ 群の間に差がみられなかっ た。また ureaやクレアチニンの排泄量にも差 がないことから, 午後の手術の場合でも, 術前 $1000 \mathrm{~m} l$ もの輸液は不要ではないかとも思われ る.ただ，輸液によって functional ECFVを増 加させることは, plasma 予備軍を増やすこと になり，術中の出血などに対しては有利であろ うし，また， H 群で水利尿がみられることより， 腎は濃縮能を働かせずともよく，堅に対しては 庇護的であるといえるかもしれない，術中の血 漿 Aldosterone を見ると，その絶対值は，上腹 部，下腹部という手術部位による差はなく， $\mathrm{ADH}$ に関しても同様ではないかと思われる が, 現在のところ不明である，今後，対象症例 や輸液方法を変えて，さらに検討する必要があ ると思われる。

本論文の要旨は, 第 1 回臨床麻酔学会総会 （1981 年 11 月，岡山）にて発表した.

\section{参考文献}

1) 河野克涁ほか：手術侵奯下における血中 Aldosterone 值に及ほす術前輸液の影䇾. 術後代謝研究会誌. $13: 218$, 1978

2 ）鵜飼光雄：手術中における vasopressin の分泌機序. 新医学 $26: 672,1971$

3) M.L. Tuck et al. : Sequential responses of the reninangiotensin-aldosterone axis to acute postural change : Effect of dietary sodium. J. Lab. Clin. Med. 86 : 754, 1975

4 ) D.M. Philbin : Anesthesia and Antidiuresis. Weekly Anesthesiology Update. Lesson 39. vol 2. 1979

5 ) Peter Hutchin: Metabolic response to surgery in Relation to Caloric Fluid and Electrolyte Intake. 
Current problems in surgery. p 11. 1971

6 ) D.M. Philbin et al. : Radioimmunoassay of Antidiuretic Hormone During Morphine Anesthesia Can. Anesth. Soc. J. 23 : 290, 1976

7 ) G.L. Robertson et al. : The osmoregulation of vasopressin. Kidney International. $10: 25,1976$

8 ）尾山力：麻酔と内分泌機能. 臨床麻酔. 3：1369. 1979
9 ) R.A. Baratz : Plasma ADH and Urinary Output during CPPB in Dogs. Anesthesiology. 34 : 501, 1971

著者連絡先 助永和子

₹ 663 西宮市武庫川町 1-1

兵庫医科大学 麻酔科

\title{
Effect of preoperative hydration on intraoperative ADH response
}

\author{
Kazuko SUKENAGA \\ Katsuakira KONO \\ Saburo TSUDA \\ Hiroatsu ISHIDA
}

Department of Anesthesia, Hyogo Medical College, Japan.

Summary We studied the effect of preoperative hydration on the secretion of ADH during surgery. 19 patients undergoing hysterectomy were devided into two groups, Control group and Hydration group, based on the amount of preoperative infusion.

Venous blood samples were obtained

(1) before starting preoperative hydration at 8:00A.M., (2) immediately prior to induction of anesthesia, (3) 15 minutes after induction of anesthesia, (4) 10 minutes after incision, (5) 30 minutes after incision, (6) 60 minutes after incision and (7) immediately after operation.

The ADH levels were (mean \pm SEM)
(1) $3.1 \pm 0.9$
(2) $3.2 \pm 0.9$
(3) $2.7 \pm 0.6$
(4) $45.1 \pm 12.7$
(5) $19.5 \pm 4.0$
(6) $\quad 17.9 \pm 5.1$ and (7) $18.6 \pm 4.1 \mathrm{pg} / \mathrm{m} l$ in the control group and (1) $3.7 \pm 0.5$ (2) $3.9 \pm 0.6$ (3) $3.1 \pm$

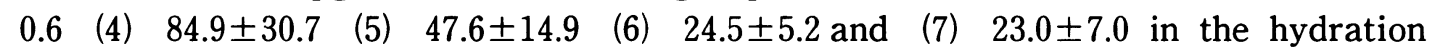
group, respectively. There was statistically no significant difference between the two groups.

Our protocol for preoperative infusion does not seem to have any inhibitory effect on the secretion of $\mathrm{ADH}$ during surgery. 